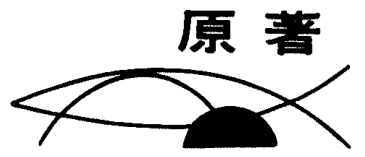

$$
\begin{aligned}
& \text { 頸椎用（六ツ切判）スクリーン・フィルム } \\
& \text { オートチェンジャー }
\end{aligned}
$$$$
\text { 沢四武 司*白川秀 紀* }
$$$$
\text { 遠藤 幸男* 石黑雅 伸* }
$$

\title{
An Autochanger of a Film and Three Screens for \\ Roentgen Examination of the Cervical Vertebra
}

\author{
Takesi Sawcda, Hideki Sirakawa \\ Yukio Endoh and Masanobu Isiguro \\ Fujita Health University Hospital
}

Summary

An autochanger of a film and three kinds of intensifying screens has been developed for cervical vertebra radiography. With this device a magagine can supply 100 sheets of 18 $\mathrm{cm} \times 24 \mathrm{~cm}$ vertical film.

A unit consists of a control box and $\mathrm{X}$-ray radiographic instrument. The operator selects properly a screen from among three intensifying screens, according to antero-posterior, lateral and oblique projection of cervical vertebra.

We will product consistently good radingraphys and reduce radiation exposure to the patient.

\section{1. 目的}

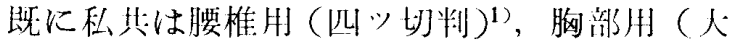
的判)2）增感紙・フィルムオートチェンジャ 一について紹介をした，次に，最後の做影装湍:

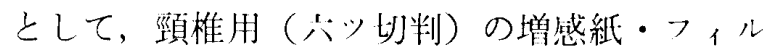
ムオートチェンジャーを陚作した。本装䠉の戈 用化にあたりここれまでの使用経験を参考にし た。この結果，1）フィルムの搬咲性:の䢹にと フイルム吸着盤のサイズを最小限にして，算直

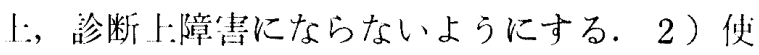
用フィルムが六ツ切判のため, 比多, 撮影年月

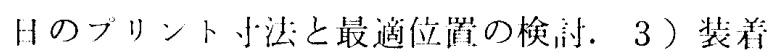
フィルム枚数を俩装箐の50枚から 100 枍と增加

*藤田保健衛生大学病院放射線部 （原稿受付：1992年 7 月 13 日）

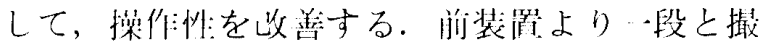
影フィルムの搬送，收納時などに，トラブルが

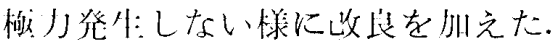

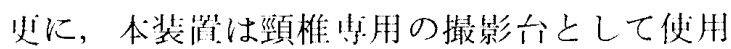
することを、腿としている。このため，作泊，

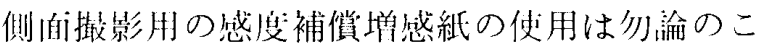
と，斜位撖影用のものについても就作装着する ことを胡町した。

以上の問题点について，公解沠のH処が方 ち，央祭に使用してみた听，份用であったので その成果を報告する。

\section{2. 研 究内 容}

\section{1 ）装置の概略}

本装置の特色はこれをでのフィルム・オート チェンジャ一とは異なり，3 種類の六ッ切判増 


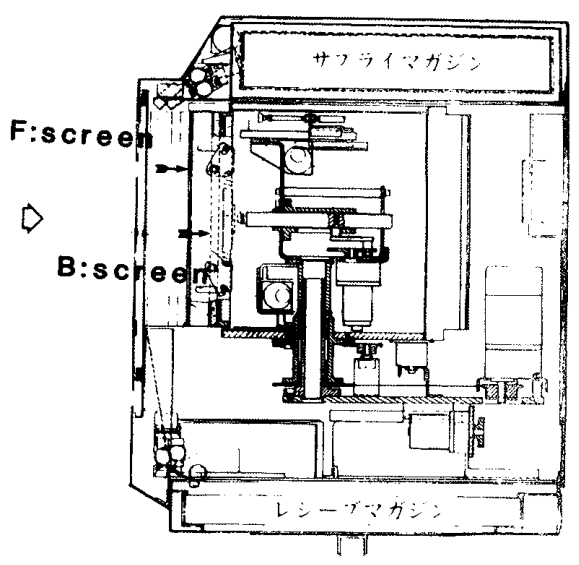

図 1 スクリーン・フィルムオートチェン ジャー (六ツ切判) の断面図
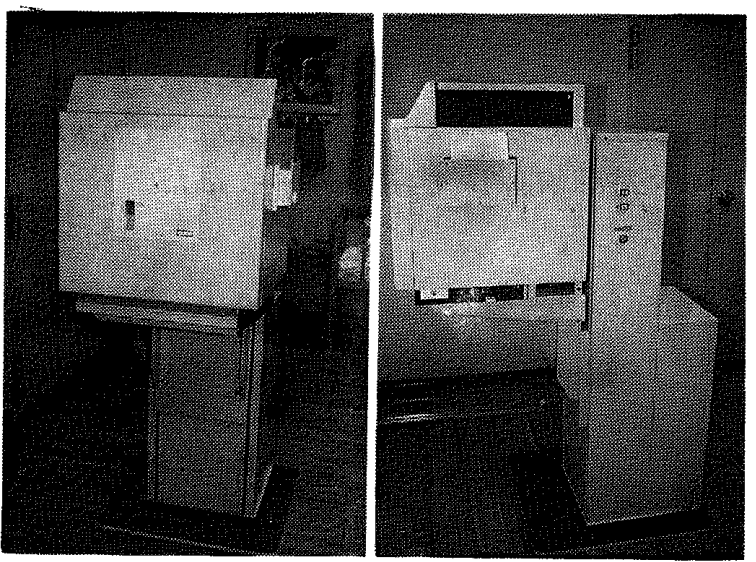

写真 1 頸椎用増感紙・フィルムオートチ エンジャー (六ツ切判) の架台

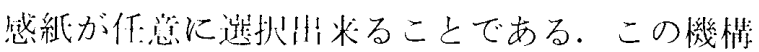

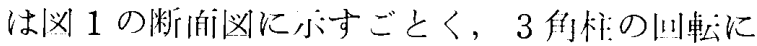

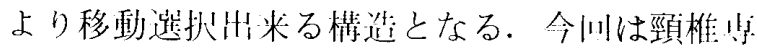

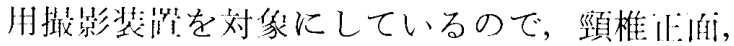

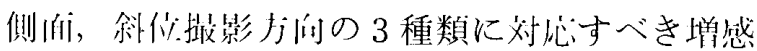
紙を非り付汁ることにした。このために，增感

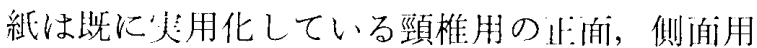
感度補償增感紙を张り付けた。この基準感度は TO-330 としたが，残りの 1 枚は，将米斜位 用の感度補償增感紙と取り笭える“定である。

このオートチェンジャーを, 山焂 DHF$155 \mathrm{~A}$ と揬絎した。掫影叫漓は $150 \mathrm{~cm}$, grid は 10:1の microfine を用いて，この後俑に

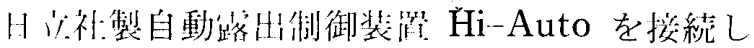
た。

他う，分ッ切判非フィルムはこれまでの50枚 より 100 枚装埧之情加した。 抽フィルム搬送用 のcontrol box の表小燈も, 增感紙の山転移動 が筞食に終厂するまでは，フィルムが搬送桼米 ない機構とした，撮影架台のX線中心点の简さ は最大 $180 \mathrm{~cm}$ 迄調整叮能として，長身の想者 でも立位で十分に撮影叮能とした（筫1）.

\section{2 ）実験内容}

(1) 頸椎用感度補傥增感紙の補償效果

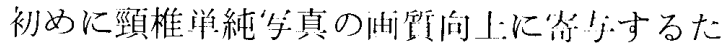
めに，このオートチェンジャーには, 頸椎用の I:泊，側面朋感度補償增感紙を装着した。この 増感紙の補償效果について確認を行った。

測定方法：X線吸収体に $8 \mathrm{~cm}$ 厚のアクリル 板を用いて，臨床検査の時之同様の撮影条件で ある管電生 $70 \mathrm{kV}$ ，管電流 $250 \mathrm{~mA}$ ，（撮影時 間のみを $12 \mathrm{~m} \mathrm{sec}$ に調整), $F F D: 150 \mathrm{~cm}$, grid : 10:1 で撮影を実施した。この撮影済つ イルムをコニカ社製等濃度分布測定器 (PDI10）で，フィルム濃度分布の計測を実施し補償 効果を確認した。

(2) Phantom 飞よる比較

次に, 頸部 Phantom を用いて正面, 側面 の補償効果を確認した。报影条件はこれまでの

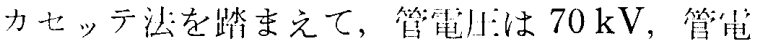

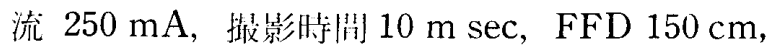
grid 10:1とした.

\section{3. 使用結果}

1) 初めに钼椎归活用の感佼補償效果の形状

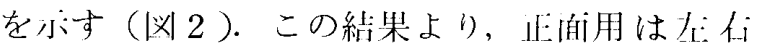

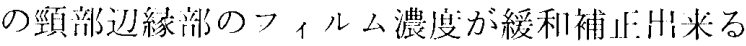

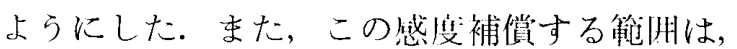
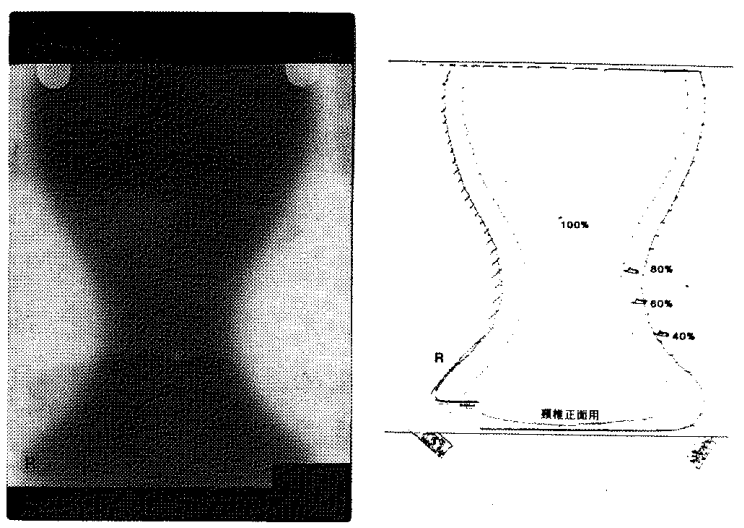

図 2 頸椎正面用感度補傥增感紙のフィルム濃 度（左側）と等濃度分布図（右側） 
医器学 Vol. 62, No. 10 (1992) ( 3 )
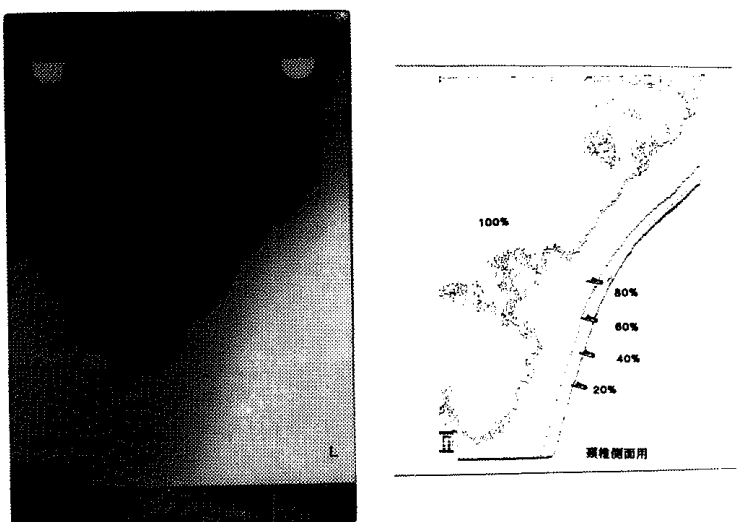

図 3 頸椎側面用感度補償増感紙のフィルム濃 度 (左側) 亡等濃度分布図 (右側)
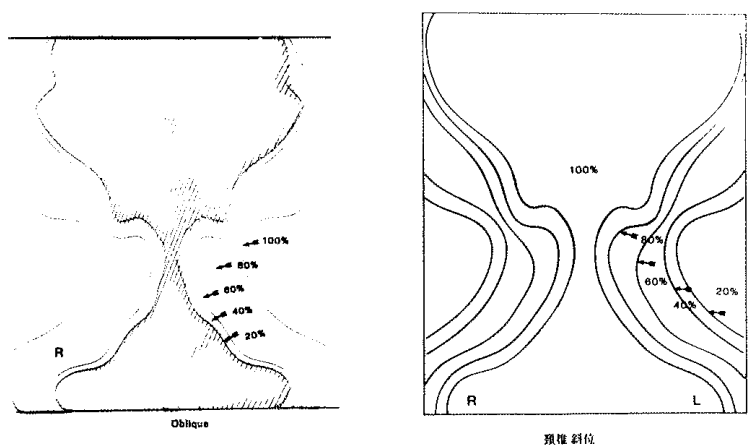

図 4 頸椎斜位用感度補侻增感紙のフィルム浱

度分布（左側）とこの形状（右側）を示す

当初フィルム濃度を補正:する日的で設計した形 状と，注とんど変わりなく同一状態に仕上がっ た.

次に頸椎側而用は，既に頸椎 $\mathrm{X}$ 線撮影時に実 用しているが收めて検湖した。この絬果，前頸 部辺䋑部のフィルム濃度が緩和補ＩF:出来た（図 $3)$.

最後は斜位用感度補償增感紙であるが，見在:

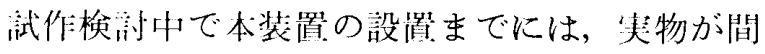
に命わなかった。刚 4 は，私其が考案した頸椎 斜位用の原型である。新製品完成後はこの部分 のみを取り替えることにする，その詳紼は別の 機会で報告したい。

2）撮影したX線'多真上り，IF自，侧面用感 度補傥增感紙によるフィルム濃度むらがなく， 読影上に障害陰影として現出することはなかっ た，又，対照にしたこれまでの通常の増感紙に

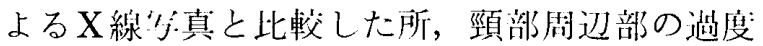
になりがちなX線つィルム濃度が，緩利され補 償效果が良く認められた（写真 $2 ， 3$ ）。
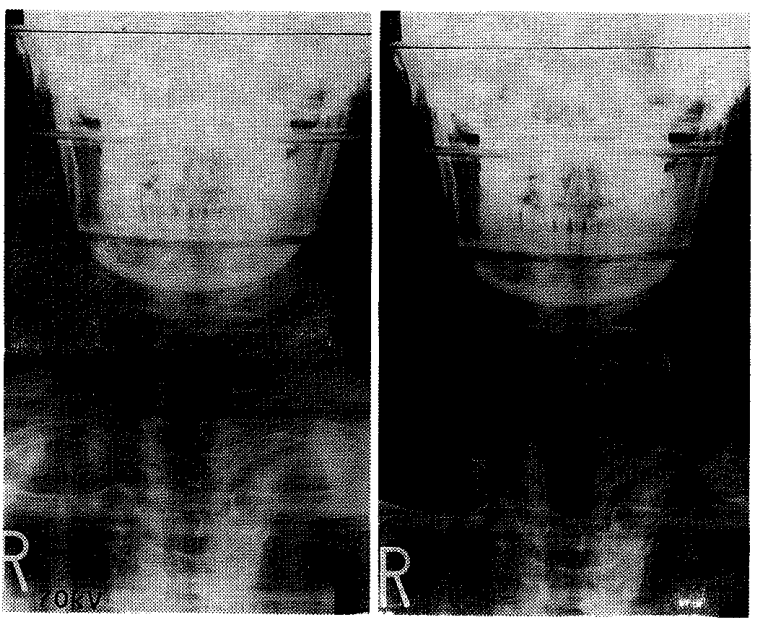

写真 2 頸椎 phantom による正面像の比較 （左側写真は感度補償增感紙を使用した時, 右側写真は通常の増感紙を使用した時）

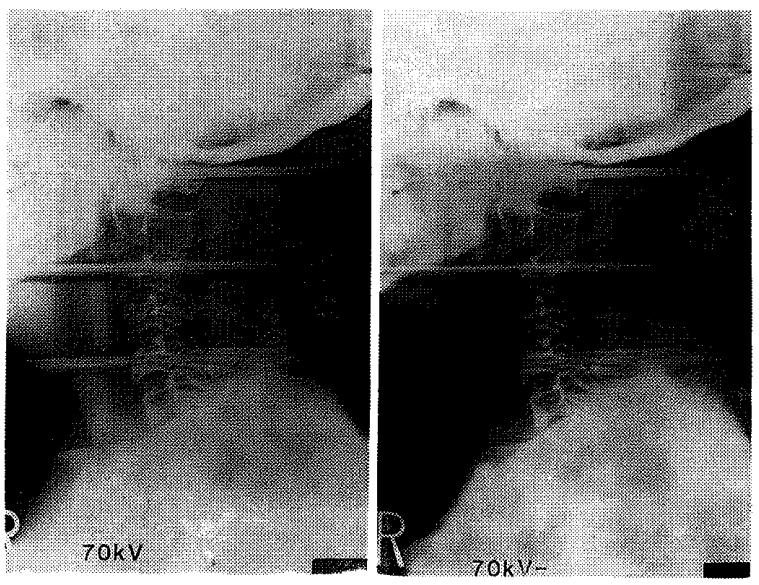

写真 3 頸椎 phantom による側面像の比較 （左側写真は感度補償増感紙を使用した時, 右側写真は通常の増感紙を使用した時）

さらに，感度補償増感紙を利用する時，被多 休の整位など撮影.ト:問題は生じないないと思 5 .

令们は希十類系增感紙 T O-330 を基準感度 として採用した。これまでのレギュラ一系増感 紙 BM-III より高感度のものに取り替えたが， 視覚的に洏者の画質を比較評価した所，何等劣 ることはなかった。

\section{4. 臨 床 写 真}

頸椎用オートチェンジャーによる撮影条件は, これまでのカセッテによる場合と同一管電生と した。従って管電压. $70 \mathrm{kV}$ ，管電流 $250 \mathrm{~mA}$, $\mathrm{FFD}: 150 \mathrm{~cm}$ とした。以下，順にX線㝍真を 


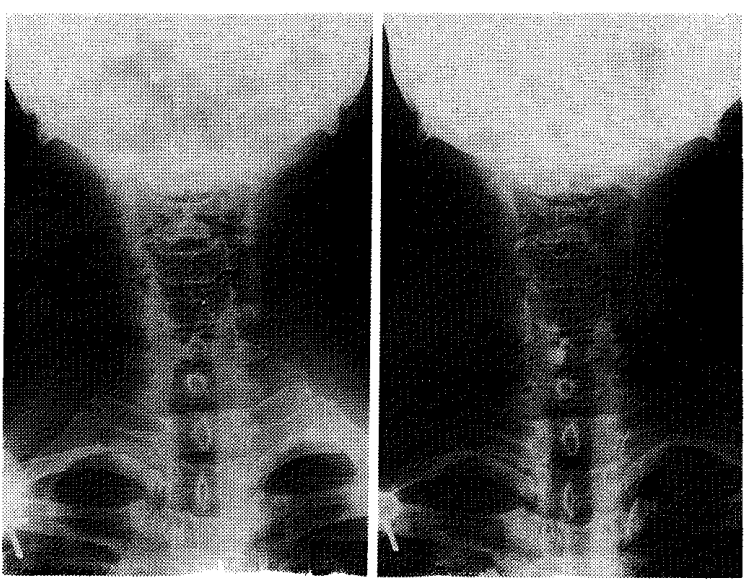

写真 4 臨床写真の比較

（左側写真は頸椎正面像を感度補償増感紙で撮 影した場合，右側写真は通常の増感紙で撮影 した場合）

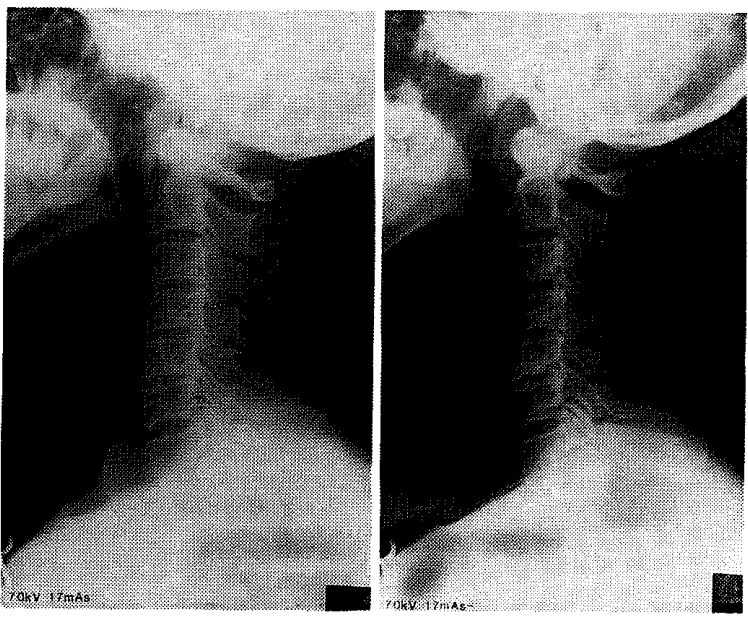

写真 5 臨床写真の比較 （左側写真は頸椎側面像を感度補䫄增感紙で撮 影した場合, 右側写真は通常の増感紙で撮影 した場合）

供覧する.

\section{1) 頸椎正面用}

頸椎止面用の感度補償增感紙による成人操影
条件は, 管電王 $70 \mathrm{kV}, 19 \mathrm{~m} \mathrm{As}$ となる. 写 真 4 の左写真が感度補償増感紙によるもので, 㮠真が通常の増感紙によるものである. 頸椎 沛側の周辺部フィルム濃度が緩和補償されて, 読影上叮視領域が挫がり，観察し易くなる.

\section{2 ）頸椎側面像}

次に頸椎側面用の感度補償増感紙による成人 標準撮影条件は，管電压 $70 \mathrm{kV}, 20 \mathrm{~m} \mathrm{As} \mathrm{と}$ なる。行真 5 の左钅真が感度補償増感紙による もので，存学真が通常の増感紙によるものであ る.この結果，前頸部の過度になりがちなフィ 几ム濃度が良く補正され，障害陰影も隹め難い。

\section{3）頸椎斜位像}

現在，頸椎斜位用の感度補償増感紙はまだ武 作中のために使用出来ない。このために，希お: 類系増感紙 T O-330 を装着した。これによる 成人標準撮影条件は，管電任 $70 \mathrm{kV}, 19 \mathrm{~mA}$ となる。

以上，選扒した各種増感紙から止着不艮によ るフィルム俩像の暈け及び，削記の頸椎感裹補 償増感紙の感度むらによる障害陰影は現出しな いことが判った，又，頸椎正自用，側面用增感 紙の選択時閒についても数秒以队の短時閌で换 わり，日常の放射線業務の省力化に充分に役的 つと茠える。

\section{5. 被曝線 量}

これまでのカ七ッテによる頸椎撮影では，レ ギュラーの記録系を利用してきた。今回のオー トチェンジャーには高感度希土類の記録系を用 いて，被曝線量の軽減に努めた.

この結果，これまでのレギュラー系では，1 枚あたりの入射線量が $25.6 \mu / \mathrm{kg}$ となった。

\begin{tabular}{|c|c|c|c|c|c|}
\hline 増感紙 撮影条件 & $\mathrm{kV}$ & $\mathrm{mA}$ & $\mathrm{mAs}$ & $\mathrm{FFD}(\mathrm{cm})$ & 被曝線量 $(\mu \mathrm{c} / \mathrm{kg})$ \\
\hline 頸椎正面方向感度補償用 & 70 & 250 & 19 & 150 & 16.5 \\
\hline 顒椎側面方向感度補償用 & 70 & 250 & 20 & 150 & 20.5 \\
\hline 頸椎前屈後屈 $\mathrm{T} \mathrm{O}-330$ & 70 & 250 & 18 & 150 & 13.1 \\
\hline 頸椎斜位方向 $\mathrm{T} \mathrm{O}-330$ & 70 & 250 & 19 & 150 & 16.5 \\
\hline $\begin{array}{l}\text { カセッテ法 } \\
\text { 頸椎正, 側面及び斜位共通 BM-III }\end{array}$ & 73 & 320 & 20 & 150 & 25.6 \\
\hline
\end{tabular}

図 5 頸椎単純撮影における入射線量の比較表 
これに対して，令问の高感度希十類の剈録系に より，正，側，斜位方问の 6 枚撮影の平均佔は $16.0 \mu \mathrm{c} / \mathrm{kg}$ まで減少蜾来た。少なくとも, 今 问の頸椎用のオートチェンジャ一の利用により, 患者へのX線被嚗線量が総線量が総線量:で 63 \%まで軽減出米た（汹５）。

\section{6. 考按}

日常診療の場で X線撮影頻度の取多の部位は, 胸部単純撮影であることは扵までもない。

この事情より既に胸部用オートチェンジャ一 は，冬施設に留及している。しかしこの状沉 トとは幾分異なるが，一患者あたりのX線掫影 でフィルム枚数が多い部位は, 頸椎, 腰椎の 6 お问撮影が硋当する。従って，私其の施設では この撮影部位の1つである钼椎X線撮影の省》 化を図るために，新しく頸椎用の六ッ切判增感 紙・フィルムオートチェンジャーを試作した。 本装置の性能は次の通りである。

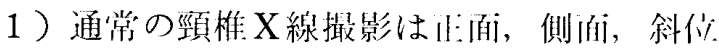
のう们が尖施されている。從って，撖影業務の 省力化を日指しては，才ートチェンジャ一を活 用するのに，箇した撮影部位の1つと考える。 又, この機会にIF面，側伯用の感度補償增感紙 を装着し䌷筫们上:に努めたが，補償効果による

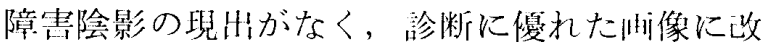
善した。・方，本装哃によりテクニカルの問题 となる患者の整位が極めて相難となって，㨴影 が出来ない事態に遭遇することはなかった。い ずれにしても，この成果を踏まえて，㠼米るだ け早い時期に, 斜位用の感度補償增感紙も筱り
简えたい。

2)これまでのカセッテでは，レギュラーの

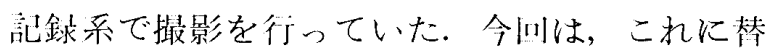
えて綗感度希卜類の記録系を採用した結果，被 暻線量が 1 枚あたり，37\% 軽減することが川 能になった。臨休I:頸椎の摄影枚数は 6 枚が槽 準のため， 1 検枉あたりの被曝線量の減少効果 は大きい。

3 ）次に本装置の架台の構造は極力小型にし, 頸椎用の白動露壮制御装促（Hi-Auto）を装着 した，採光野に被写体がはみ出すこともなく， 门動露出装置への動作にも問題はなかった。

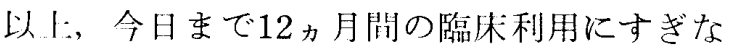
いが，本装置の設置によりX線撮影業務の省力 化に简多でき仿用な機器であった。この間装置。 门身に大きなトラブルは無く、現在まで順調に 稼動している.

\section{7. まとめ}

頸椎用（分ツ切判）スクリーン・フィルムオ 一トチェンジーの利用によりこれれでのカセ ッテの使用による撮影所用時間に比較して，1 被検者あたり半分で済及，放射線業狢の省力化

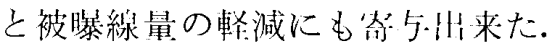

\section{考文 献}

1）沢田武司他：四切判増感紙及びフィルムオート チェンジャ一の試作，映像情報 (M), Vol, 22, 8, 1990.

2）沢田武司他：大角判増感紙及びフィルムオート チェンジャ一の試作. 映像情報 (M), 5, 1991. 